\title{
Memory Impairment in Transgenic Alzheimer Mice Requires Cellular Prion Protein
}

\author{
David A. Gimbel, ${ }^{\star}$ Haakon B. Nygaard, ${ }^{*}$ Erin E. Coffey, Erik C. Gunther, Juha Laurén, Zachary A. Gimbel, \\ and Stephen M. Strittmatter \\ Cellular Neuroscience, Neurodegeneration, and Repair Program, Yale University School of Medicine, New Haven, Connecticut 06536
}

Soluble oligomers of the amyloid- $\beta$ (A $\beta$ ) peptide are thought to play a key role in the pathophysiology of Alzheimer's disease (AD). Recently, we reported that synthetic $\mathrm{A} \beta$ oligomers bind to cellular prion protein $\left(\operatorname{PrP}^{\mathrm{C}}\right)$ and that this interaction is required for suppression of synaptic plasticity in hippocampal slices by oligomeric $\mathrm{A} \beta$ peptide. We hypothesized that $\operatorname{PrP}^{\mathrm{C}}$ is essential for the ability of brain-derived $\mathrm{A} \beta$ to suppress cognitive function. Here, we crossed familial AD transgenes encoding APPswe and PSen $1 \Delta \mathrm{E} 9$ into Prnp-1- mice to examine the necessity of $\operatorname{PrP}^{\mathrm{C}}$ for AD-related phenotypes. Neither APP expression nor $\mathrm{A} \beta$ level is altered by $\operatorname{PrP}^{\mathrm{C}}$ absence in this transgenic $\mathrm{AD}$ model, and astrogliosis is unchanged. However, deletion of $\operatorname{PrP}^{\mathrm{C}}$ expression rescues 5-HT axonal degeneration, loss of synaptic markers, and early death in APPswe/PSen1 $\Delta$ E9 transgenic mice. The AD transgenic mice with intact $\operatorname{PrP}^{\mathrm{C}}$ expression exhibit deficits in spatial learning and memory. Mice lacking $\operatorname{PrP}^{\mathrm{C}}$, but containing $\mathrm{A} \beta$ plaque derived from $\mathrm{APPswe} /$ $\mathrm{PSen} 1 \Delta \mathrm{E} 9$ transgenes, show no detectable impairment of spatial learning and memory. Thus, deletion of $\operatorname{PrP}^{\mathrm{C}}$ expression dissociates $\mathrm{A} \beta$ accumulation from behavioral impairment in these $\mathrm{AD}$ mice, with the cognitive deficits selectively requiring $\operatorname{PrP}^{\mathrm{C}}$.

\section{Introduction}

In Alzheimer's disease (AD), the amyloid- $\beta$ peptide accumulates in plaques while synapses are lost and the brain becomes dysfunctional. Soluble $A \beta$ oligomer species have been implicated in the synaptic loss and the dementia of AD (Hsia et al., 1999; Mucke et al., 2000b). A $\beta$ oligomers with deleterious effects on synaptic function have been prepared from synthetic peptide, from cell culture supernatants, and from brain extracts (Lambert et al., 1998; Walsh et al., 2002; Cleary et al., 2005; Lesné et al., 2006; Shankar et al., 2008). We searched for high-affinity oligomericspecific A $\beta$-binding sites and identified cellular prion protein, $\operatorname{PrP}^{\mathrm{C}}$ (Laurén et al., 2009).

Our previous demonstration of $\mathrm{A} \beta$ oligomer binding to $\operatorname{Pr} \mathrm{P}^{\mathrm{C}}$ used synthetic peptide (Laurén et al., 2009), but did not explore whether the action of brain-derived $A \beta$ species interact with $\operatorname{PrP}^{\mathrm{C}}$. Earlier work also demonstrated a requirement of $\operatorname{PrP}^{\mathrm{C}}$ for acute $A \beta$ oligomer suppression of synaptic plasticity in hippocampal slices (Laurén et al., 2009), leaving open the possibility that $\mathrm{A} \beta$ oligomer action to disrupt memory uses different or multiple pathways. A recent paper confirmed that $\operatorname{PrP}^{\mathrm{C}}$ is a highaffinity binding site for $A \beta$ oligomers, but suggested that memory impairment by acute $\mathrm{A} \beta$ injection does not require $\operatorname{PrP}^{\mathrm{C}}$ (Balducci et al., 2010).

\footnotetext{
Received Jan. 23, 2010; revised March 12, 2010; accepted March 30, 2010.

H.B.N. is a Brown-Coxe Postdoctoral Fellow and S.M.S. is a member of the Kavli Institute for Neuroscience at Yale University. We acknowledge support from the National Institutes of Health, the Falk Medical Research Trust, an anonymous donor, the Alzheimer's Association, and the Cure Alzheimer's Fund to S.M.S.

*D.A.G. and H.B.N. contributed equally to this work.

Correspondence should be addressed to Stephen M. Strittmatter, Cellular Neuroscience, Neurodegeneration and Repair Program, Yale University School of Medicine, 295 Congress Avenue, New Haven, С 06536. E-mail: stephen. strittmatter@yale.edu.

DOI:10.1523/JNEUROSCI.0395-10.2010

Copyright $\odot 2010$ the authors $\quad 0270-6474 / 10 / 306367-08 \$ 15.00 / 0$
}

To extend analysis of $\operatorname{PrP}^{\mathrm{C}}$ function in $\mathrm{AD}$ models, we examined spatial learning and memory in transgenic APPswe/ PSen1 $\Delta$ E9 mice (Jankowsky et al., 2004) with and without $\operatorname{PrP}^{\mathrm{C}}$ (Manson et al., 1994). Since the manifestation of several other neurodegenerative conditions in mice is not altered by loss of $\operatorname{PrP}^{\mathrm{C}}$ expression (Steele et al., 2009), this paradigm assesses the role of $\mathrm{PrP}^{\mathrm{C}}$ in pathways specific to the APPswe/PSen $1 \Delta \mathrm{E} 9$ condition. Our hypothesis predicts that $\operatorname{PrP}^{\mathrm{C}}$ functions downstream of $A \beta$ production but upstream of intracellular toxicity within neurons, and for this reason, we did not examine transgenic Tauinduced mouse phenotypes.

Here, we report that $\mathrm{AD}$ transgenic mice lacking $\operatorname{PrP}^{\mathrm{C}}$ accumulate $\mathrm{A} \beta$, but show normal survival and no loss of spatial learning and memory.

\section{Materials and Methods}

Mice. The APPswe/PSen $1 \Delta \mathrm{E} 9$-coinjected transgenic mice (Jankowsky et al., 2004) were obtained from The Jackson Laboratory, and Prnp-/mice (Edinburgh strain) (Manson et al., 1994) were obtained from Dr. Chesebro of the Rocky Mountain Laboratories. Both strains were extensively backcrossed ( $>10$ generations) onto the C57BL/6J background and were maintained on this strain background.

Brain tissue collection. Mice were killed and immediately perfused with ice-cold $0.9 \% \mathrm{NaCl}$ for $2 \mathrm{~min}$. The brains were then dissected out and placed in ice-cold $0.9 \% \mathrm{NaCl}$. For biochemical analysis, the right posterior part of the brain extending to the hippocampus was weighed and immediately frozen in $-80^{\circ}$. To extract the soluble/cytosolic fraction, the brains were homogenized in three volumes (w/v) of $50 \mathrm{~mm}$ Tris- $\mathrm{HCl}, 150$ $\mathrm{mm} \mathrm{NaCl}, \mathrm{pH} 7.6$ (TBS) containing a protease inhibitor cocktail (Roche Complete \#10745000), 1 mm sodium orthovanadate, and 50 mm sodium fluoride. Tissue was homogenized using an ultrasonic cell disruptor (U1trasonic Power), and ultracentrifuged at $100,000 \times g$ for $20 \mathrm{~min}$ at $4^{\circ}$. The supernatant was mixed with $4 \times$ SDS-PAGE loading buffer, boiled for 5 min, and stored for subsequent analysis. The pellet was then resuspended 
to the same volume as the original homogenate in TBS with $2 \%$ Triton X-100 (American Bioanalytical), 0.1\% SDS (American Bioanalytical), a protease inhibitor cocktail (Roche Complete \#10745000), 1 mm sodium orthovanadate, and $50 \mathrm{~mm}$ sodium fluoride. Tissue was homogenized and ultracentrifuged at $100,000 \times g$ for $20 \mathrm{~min}$. The supernatant was mixed with $4 \times$ SDS-PAGE loading buffer, boiled for $5 \mathrm{~min}$, and stored for subsequent analysis. The remaining pellet was then resuspended to the same volume in $0.1 \mathrm{M}$ formic acid, homogenized, and ultracentrifuged, and the supernatant was frozen after neutralizing $\mathrm{pH}$ with $50 \mu \mathrm{l}$ of $1 \mathrm{~m}$ Trizma-base. The remaining pellet was then resuspended to the same volume in $6 \mathrm{~N}$ guanidine- $\mathrm{HCl}$ (American Bioanalytical), homogenized, and ultracentrifuged, and the supernatant was frozen for subsequent analysis.

Immunohistochemistry. One hemisection containing the frontal cortex was immersed in fresh $4 \%$ paraformaldehyde (PFA) overnight. After the brains were fixed, they were embedded in $10 \%$ gelatin and placed in $4 \%$ PFA for $20 \mathrm{~h}$ at $4^{\circ} \mathrm{C}$. Parasagittal sections $(30 \mu \mathrm{m})$ were then cut using a Leica WT1000S vibratome. For immunohistochemistry, sections were blocked in $10 \%$ donkey serum for $1 \mathrm{~h}$, followed by incubation with primary antibody overnight at $23^{\circ}$. Primary antibodies were diluted in PBS with $0.2 \%$ Triton X-100 (American Bioanalytical). The following antibodies were used: $\beta$-amyloid antibody (Cell Signaling Technology \#2454, and Millipore 6E10 MAB 1560, both 1:250), 5-HT (Immunostar \#20080, 1:16,000), PSD-95 (Invitrogen \#51-6900, 1:250), GFAP (Sigma \#C9205, 1:2500), and synaptophysin (Millipore MAB5258, 1:1000). Following incubation, the sections were washed three times with PBS, and incubated in secondary fluorescent antibody (Invitrogen Alexa Fluor donkey anti-rabbit or anti-mouse, all 1:500) for $2 \mathrm{~h}$ at room temperature (RT). The slices were then washed three times and transferred to PBS. Each free-floating section was mounted on a microscope slide (Fisherbrand Superfrost/Plus) and coverslipped using fluorescent mounting medium (Vector Laboratories \#H-1000).

Imaging and analysis. All images and analyses were generated by personnel without knowledge of the mouse genotype. $\beta$-Amyloid images were obtained using a Zeiss AxioImager Z1 fluorescent microscope with a $10 \times$ objective. Mosaic images of the entire frontal cortex from each animal were obtained and analyzed, and plaque burden was calculated using ImageJ. The fractional area occupied by GFAP-positive astrocytes from the frontal cortex was measured by computer-assisted analysis of images obtained at $20 \times$ objective magnification.

$Z$-stack images of 5-HT-labeled slices (30 $\mu \mathrm{m}$ stack of 15 images at 2 $\mu \mathrm{m}$ spacing) were obtained using an UltraView VoX spinning disc confocal microscope (PerkinElmer). Optical stacks from two sites in the frontal cortex were obtained using a $20 \times$ objective, and images were projected using Adobe Photoshop. All images were in the sagittal plane and were carefully matched for location in the rostral-caudal $(1 \mathrm{~mm}$ posterior to bregma) and medial-lateral (1 $\mathrm{mm}$ lateral from midline) directions. All individual serotonin fibers within each image were traced and the total unit length of axon per area in the sagittal plane is reported, as described previously in our spinal cord studies (GrandPré et al., 2002; Kim et al., 2004; Li et al., 2004, 2005; Wang et al., 2006, 2009; Duffy et al., 2009), and in studies of cerebral cortex 5-HT innervation (Mamounas et al., 2000; Austin et al., 2002; Grider et al., 2006).

Using the UltraView VoX spinning disc confocal microscope (PerkinElmer), synaptophysin and PSD-95-immunoreactive puncta were imaged with a $100 \times$ objective in sections of the frontal lobe of cerebral cortex. Four to eight parasagittal images were obtained from two slices from each of 9-10 mice per genotype. Thus, the measurements for each genotype derived from 60 images with 100-200 synaptic puncta per image, or $\sim 10,000$ synaptic puncta per genotype. The fractional area occupied by immunoreactive puncta from frontal cortex was measured as described (Masliah et al., 1992; Buttini et al., 1999; Mucke et al., 2000a; Chin et al., 2004; Buttini et al., 2005; Linhoff et al., 2009) using ImageJ, excluding cell somata.

Immunoblots. Precast 10\% tris-glycine or 10-20\% tris-tricine gels were used (Bio-Rad). After transfer, the PVDF membranes (Bio-Rad \#162-0174) were incubated in blocking buffer for $1 \mathrm{~h}$ at RT (Licor Odyssey blocking buffer \#927-4000). Membranes were then washed five times in TBST, and incubated overnight in primary antibodies. The following antibodies were used: 6E10 (Millipore MAB 1560 1:1000), 22C11 (Millipore MAB 348, 1:100), 6D11 (Covance 39810-500, 1:500), and actin (Santa Cruz Biotechnology \#SC1616, 1:200). All antibodies were diluted in Odyssey blocking buffer, and membranes were incubated overnight at $4^{\circ}$. Following primary antibody incubation, the membranes were washed five times with TBST, and secondary antibodies were applied for $1 \mathrm{~h}$ at $23^{\circ}$ (Odyssey donkey anti-mouse or anti-goat IRDye 680 or 800 ). Membranes were then washed and proteins visualized using a Licor Odyssey Infrared imaging system. Blots were analyzed using ImageJ, and normalized to actin optical density.

Behavioral studies. Animals were randomized and the experimenter blinded to genotype for the duration of behavioral testing.

Morris Water Maze testing (Vorhees and Williams, 2006) was performed over the course of $6 \mathrm{~d}$ and consisted of a $3 \mathrm{~d}$ learning trial and a $3 \mathrm{~d}$ reversal trial. Both trials were performed in an open-water pool $\sim 1 \mathrm{~m}$ in diameter and used a submerged, nonvisible escape platform located in the center of one of the pool's four quadrants. This location remained constant for each $3 \mathrm{~d}$ trial; for the reversal trial, the platform was placed, for the duration of the trial, in the quadrant diagonally across from its original location in the learning trial. Over the course of each testing day, an animal swam a total of eight times - four times in the morning, constituting one "block" of swims, and four times in an afternoon block. Over the course of a block, each mouse would begin its swim in each of four distinct locations around the wall of the pool, and was timed for its latency to reach the escape platform for a maximum time of $1 \mathrm{~min}$. If the mouse did not find the submerged platform within $1 \mathrm{~min}$, it was removed from the water and placed on the platform for $\sim 10 \mathrm{~s}$ before being taken from the pool.

The water maze probe trial was performed $2 \mathrm{~d}$ following the third and last day of the reversal trial, and in the same $1 \mathrm{~m}$ pool described above. For the purposes of the probe trial, the platform was removed from the pool; all mice were started from a location along the pool wall diagonally opposed to the location of the platform in the reversal trial and permitted to swim for $1 \mathrm{~min}$. The probe trials were recorded on a JVC Everio G-series camcorder and analyzed using Panlab's Smart tracking and analysis program, $\mathrm{v} 2.5$.

A block of five swims to a visible platform was conducted after the probe trial.

Passive avoidance testing (King et al., 2003) was performed over the course of $3 \mathrm{~d}$ after water maze testing was complete. On the first day of testing, each subject was permitted $5 \mathrm{~min}$ to explore the passive avoidance apparatus, which consisted of two chambers, one well lit and one dark, connected by a door and sharing a metal grid floor through which current might be passed. The door between the light and dark boxes remained open for the duration of the $5 \mathrm{~min}$, and no shock was administered. The second day of testing consisted of a single "shock trial." Each animal was placed in the light box to begin and, upon entry into the dark box, the dividing door closed, and the mouse was subjected to a shock of $0.5 \mathrm{~mA}$, duration $2 \mathrm{~s}$; time to entry was recorded. On the third day of testing, each animal was placed in the light box to start, and its time to enter the dark box was recorded. No shock was administered. The following were constant settings throughout the $3 \mathrm{~d}$ experiment: door delay $=1 \mathrm{~s}$, cutoff time $=5 \mathrm{~min}$. Passive avoidance testing was performed using Ugo Basile's 7550 line passive avoidance set-up (step-through method) with model 7553 (mouse-specific apparatus).

Statistical analysis. Repeated-measures two-way and one-way ANOVA tests were prepared using SPSS software.

\section{Results}

Mice with one of four genotypes were generated on an inbred C57BL/6J background, with and without the APPswe/PSen $1 \Delta \mathrm{E} 9$ transgene on the wild-type or Prnp-/- background. At 12 months of age, these mice were killed and the brain tissue was examined histochemically and biochemically. Since the reported interactions of $\mathrm{A} \beta$ and $\operatorname{PrP}^{\mathrm{C}}$ are posttranslational, the overall expression of APP and $\mathrm{PrP}^{\mathrm{C}}$ is not predicted to be altered by the status of the other gene. Indeed, levels of sAPP (22C11) and $\operatorname{sAPP} \alpha(6 \mathrm{E} 10)$ in the transgene-positive animals are indistin- 
a

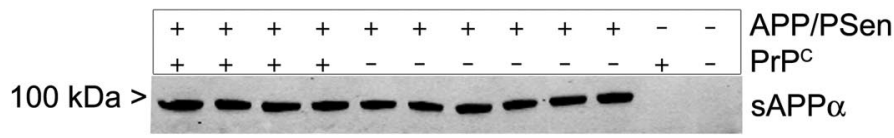

b



C

$3.8 \mathrm{kDa}>$

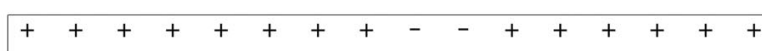

d

$16 \mathrm{k}$

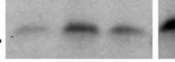

$16 \mathrm{kDa}>$

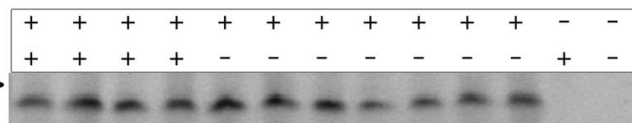

e

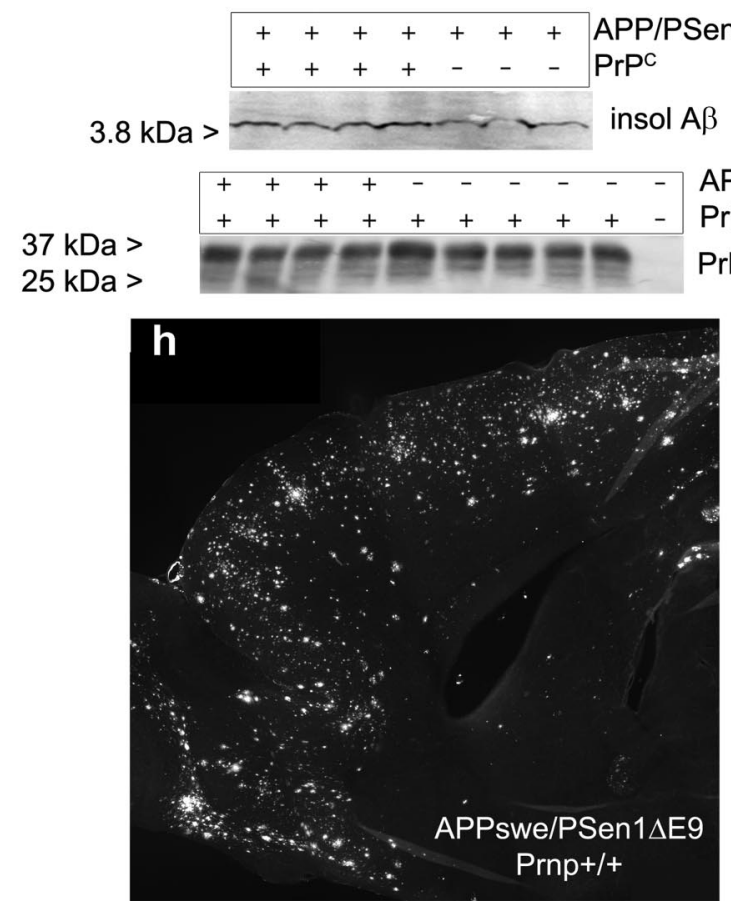

g
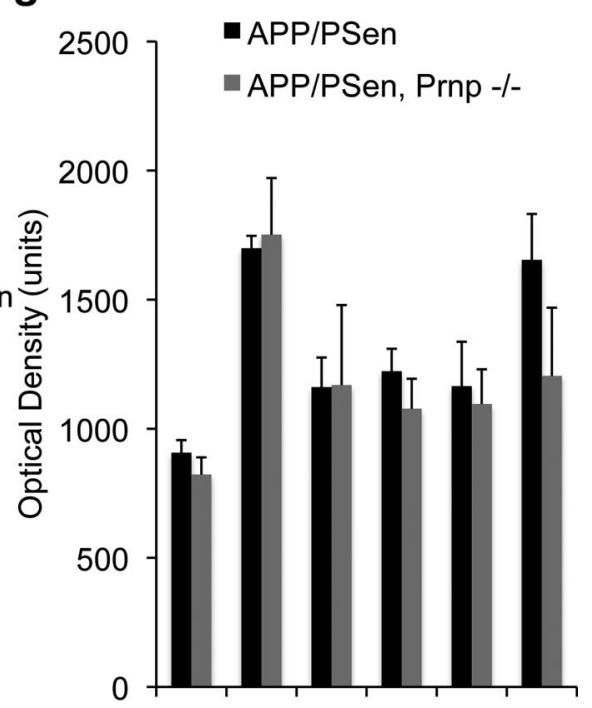

APP/PSen $\mathrm{PrPC}^{\mathrm{C}}$ APP/PSen $\beta C T F$

(1)

i

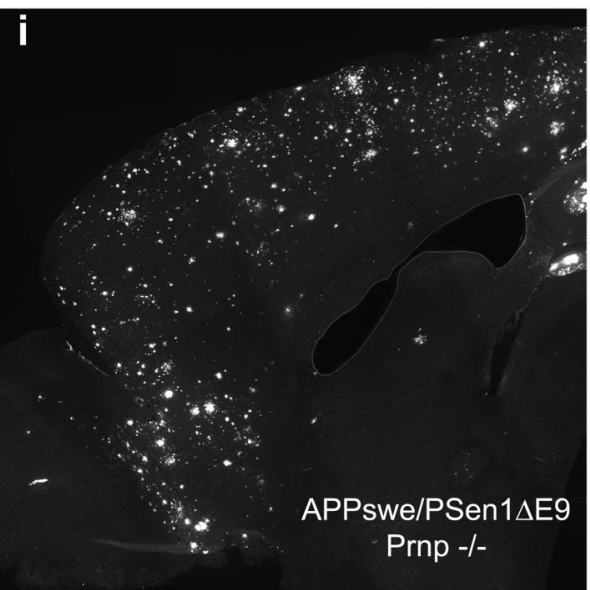

Figure 1. APP and A $\beta$ levels are not dependent on $\operatorname{PrP}^{C}$. $\boldsymbol{a}-\boldsymbol{f}$, Immunoblot analysis of soluble brain extracts $(\boldsymbol{a}-\boldsymbol{c}, \boldsymbol{f})$ or detergent-extracted particulate fractions $(\boldsymbol{d})$ or guanidinium-solubilized material (e) with anti-A $\beta 6$ E10 antibody $(\boldsymbol{a}, \boldsymbol{c}-\boldsymbol{e})$, anti-APP 22C11 antibody $(\boldsymbol{b})$, or anti-PrP $6 \mathrm{D} 11$ antibody $(\boldsymbol{f})$. Genotype is indicated at the top of each blot for separate mice. The migration of MW standards is shown at the left. $\boldsymbol{g}$, Densitometric analysis of immunoblot signals from experiments as in $\boldsymbol{a}-\boldsymbol{f}$. Data are mean \pm SEM for $n=5-12$ mice per genotype. $\boldsymbol{h}, \boldsymbol{i}$, Immunofluorescent detection of $A \beta$ in a parasagittal section of the anterior half of a APPswe/PSen1 $\Delta$ E9 transgenic mouse brain at 12 months of age of the Prnp $+/+(\boldsymbol{h})$ or Prnp $-/-(\boldsymbol{i})$ genotype.

guishable between the wild-type and Prnp-/- backgrounds (Fig. $1 a, b, g)$. Similarly, $\operatorname{PrP}^{\mathrm{C}}$ levels are not different in brain extracts of mice with and without the APPswe/PSen $1 \Delta \mathrm{E} 9$ transgene (Fig. 1f).

The processing of APP produces membrane-associated $\mathrm{C}$-terminal fragments and soluble $A \beta$ species. Immunoblot of detergent extracts of the particulate phase reveals no effect of Prnp genotype on $\beta$-CTF detected with 6E10 antibody (Fig. $1 d, g$ ). Soluble monomeric $\mathrm{A} \beta$ levels in brain homogenates prepared under non-denaturing conditions show no correlation with $\operatorname{PrP}^{\mathrm{C}}$ level (Fig. 1c,g). Thus, APP metabolism is independent of $\operatorname{PrP}^{\mathrm{C}}$.

A role for $\operatorname{PrP}^{C}$ in mediating $A \beta$ oligomer synaptotoxicity is downstream of $A \beta$ production and is not required for $A \beta$ fibrillization, so $A \beta$ plaque load is not predicted to be altered by the status of $\operatorname{PrP}^{\mathrm{C}}$ expression. The level of $\mathrm{A} \beta$ extracted from APPswe/PSen1 $\Delta \mathrm{E} 9$ brain homogenates by formic acid or guanidinium- $\mathrm{HCl}$ from the particulate phase is not altered by status of the Prnp gene (Fig. 1e,g). Similarly, the burden of A $\beta$-immuno- reactive plaque is altered minimally in APPswe/PSen $1 \Delta \mathrm{E} 9$ transgenic brain without $\operatorname{PrP}^{\mathrm{C}}$ as compared to that with $\mathrm{PrP}^{\mathrm{C}}$ (Fig. $1 h, i), 8.3 \pm 0.5$ versus $10.4 \pm 0.7$ as a percentage of brain area. Minimal effects of $\operatorname{PrP}^{\mathrm{C}}$ on $\mathrm{A} \beta$ level are generally consistent with previous observations of a minor increase in $\mathrm{A} \beta$ plaque in $\mathrm{PrP}^{\mathrm{C}}$ overexpressing APPswe transgenic mice (Schwarze-Eicker et al., 2005) and a slight increase of mouse A $\beta$ levels in Prnp-/- mice (Parkin et al., 2007).

While the synaptic action of $A \beta$ oligomer is hypothesized to be mediated by $\operatorname{PrP}^{\mathrm{C}}$, the non-neuronal reaction to $\mathrm{A} \beta$ plaque deposition may occur through alternate cellular receptors. We assessed astrogliosis in the APPswe/PSen $1 \Delta \mathrm{E} 9$ brains histologically (Fig. 2a). Familial AD transgene expression increased GFAP-positive area, but deletion of $\operatorname{PrP}^{\mathrm{C}}$ expression did not alter the astrocyte reaction. Thus, APP expression, $\mathrm{A} \beta$ level, and gliosis are not altered by deletion of $\operatorname{PrP}^{\mathrm{C}}$.

Having shown that $\operatorname{PrP}^{\mathrm{C}}$ has little effect on $\mathrm{A} \beta$ metabolism, we assessed its role in mediating the deleterious chronic effects of 
brain-derived $\mathrm{A} \beta$ in vivo on neuronal form and function, focusing on measures that cannot be modeled in vitro. $\mathrm{A} \beta$ dependent neurodegeneration in transgenic mice is not as pronounced as it is in human $\mathrm{AD}$, but restricted aspects of degeneration have been reported by assessment of monoaminergic pathways (Liu et al., 2008). An examination of serotoninimmunoreactive fibers in the cerebral cortex reveals significant deficits in the APPswe/PSen $1 \Delta \mathrm{E} 9$ mice at 12 months of age (Fig. 2b,c), matching the selective degeneration described previously (Liu et al., 2008). At this age, axonal degeneration occurs, but serotonergic cell loss is not yet detectable (Liu et al., 2008). The appearance of 5-HT-immunopositive axons in Prnp-/- mice is similar to that in wildtype mice. In the transgenic APPswe/ PSen $1 \Delta$ E9 mice lacking $\operatorname{PrP}^{\mathrm{C}}$, 5-HTimmunoreactive fibers are indistinguishable from control mice and significantly preserved relative to APPswe/PSen $1 \Delta \mathrm{E} 9$ mice with $\operatorname{PrP}^{\mathrm{C}}$. Thus, this transgenic ADlike axon degeneration phenotype is dependent on $\operatorname{PrP}^{\mathrm{C}}$.

Synapse loss has been considered a hallmark of $\mathrm{AD}$ and been detected in transgenic models (Davies et al., 1987; Scheff et al., 1990; Hsia et al., 1999; Mucke et al., 2000b; Biscaro et al., 2009). We examined a presynaptic marker, antisynaptophysin, and a postsynaptic marker, anti-PSD-95, in separate sections (Fig. $2 d-$ $f$ ). The immunopositive area for either of these markers is slightly, but significantly, reduced in cortical sections from APPswe/ PSen $1 \Delta \mathrm{E} 9$ mice. Nontransgenic brain lacking $\operatorname{PrP}^{\mathrm{C}}$ exhibits no alteration of these markers relative to wild type. In contrast, the APPswe/PSen $1 \Delta$ E9, Prnp-/- brain shows an increased area occupied by both markers relative to APPswe/PSen $1 \Delta \mathrm{E} 9$ samples with $\operatorname{PrP}^{\mathrm{C}}$, and is indistinguishable from wildtype brain by these measures. Thus, the loss of synaptic marker area caused by APPswe/ PSen $1 \Delta \mathrm{E} 9$ expression is rescued by a lack of $\mathrm{PrP}^{\mathrm{C}}$ expression.

An obvious but incompletely understood phenotype of the AD transgenic mice is reduced survival, characterized by sudden death occurring in the adult period. This phenotype may result from hyperexcitability and status epilepticus (Palop et al., 2007; Minkeviciene et al., 2009). Mouse survival was monitored between 0 and 12 months of age, with $40 \%$ of APPswe/PSen $1 \Delta \mathrm{E} 9$ transgenic mice being lost (Fig. 3), similar to previous reports for this strain (Halford and Russell, 2009). In contrast, $<4 \%$ of APPswe/ PSen $1 \Delta$ E9 mice lacking $\operatorname{PrP}^{\mathrm{C}}$ died during
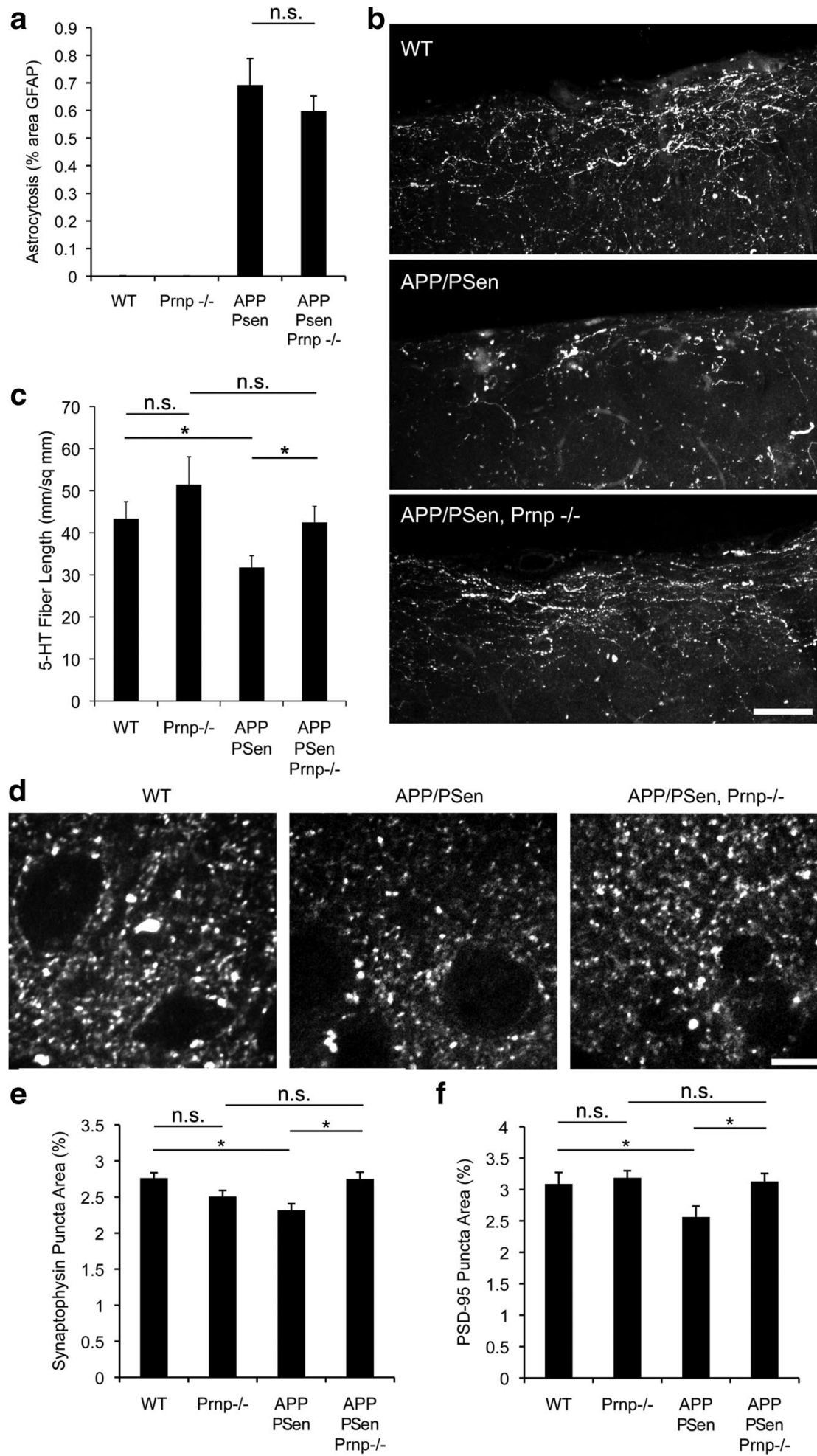

Figure 2. Serotonin axons and synaptic markers are preserved in APPswe/PSen $1 \Delta$ E9 mice lacking PrP ${ }^{C} . \boldsymbol{a}$, Anti-GFAP immunohistology of parasagittal brain sections was scored for astrocytic area in the anterior half of the cerebral cortex. Data are mean \pm SEM for $n=10$ mice per genotype. $\boldsymbol{b}$, Parasagittal sections of cerebral cortex from mice of the indicated genotypes were stained with anti-5-HT. Projections of $30 \mu \mathrm{m}$ confocal Z-stacks are shown. Note the reduced fiber length in the APPswe/PSen $1 \Delta$ E9 sample. Scale bar, $50 \mu \mathrm{m}$. c, The 5-HT-immunoreactive fiber length in the parasagittal plane from images as in $\boldsymbol{b}$ was measured. Data are mean \pm SEM for $n=10-16$ mice per genotype. ${ }^{*} p<0.05$, one-way ANOVA with post hoc comparisons as indicated; $n . S$., no significant difference. $\boldsymbol{d}$, Cerebral cortex from mice of the indicated genotypes was stained with anti-synaptophysin antibody and imaged by confocal microscopy with a $100 \times$ objective. Scale bar, $10 \mu \mathrm{m} . \boldsymbol{e}, \boldsymbol{f}$, The fractional area of immunoreactive puncta from images as in $\boldsymbol{d}$ is reported as a function of genotype. Sections were stained with anti-synaptophysin (e) or anti-PSD-95 (f). Data are mean \pm SEM for $n=4-8$ sites from each of $9-10$ mice per genotype. ${ }^{*} p<0.05$, one-way ANOVA with post hoc comparisons. 




Figure 3. Survival of APP-PSen mice improved by absence of $\operatorname{PrP}^{C}$. Survival of wild-type and APPswe/PSen1 $\triangle E 9$ transgenic mice with and without PrP C expression. Survival of the APPswe/ $\mathrm{PS}$ 1 $1 \Delta \mathrm{E} 9$ mice is significantly shorter than each of the other three genotypes by the Wilcoxon statistic $(p<0.005)$.

the same age period ( $p<0.005)$. The rescue of survival in the Prnp-1- group demonstrates that death in the transgenic group requires endogenous $\operatorname{PrP}^{\mathrm{C}}$.

Previously, we examined the in vitro requirement of $\operatorname{PrP}^{\mathrm{C}}$ for acute $A \beta$ suppression of CA1-LTP in hippocampal slices. While some strains of FAD transgenic mice have been shown to exhibit spatial memory deficits (Chen et al., 2000), deficits of CA1-LTP are not uniform, being present in some cases (Nalbantoglu et al., 1997; Chapman et al., 1999; Moechars et al., 1999; Trinchese et al., 2004) but not in others (Hsia et al., 1999; Larson et al., 1999; Fitzjohn et al., 2001; Roder et al., 2003; Gureviciene et al., 2004; Volianskis et al., 2008). We observed no deficit in the magnitude of this form of LTP in hippocampal slices of 12-month-old plaque-bearing APPswe/PSen-1 $\Delta \mathrm{E} 9$ mice (supplemental Fig. 1, available at www.jneurosci.org as supplemental material), consistent with previous studies of this strain (Volianskis et al., 2008). There was a slight reduction of hippocampal input-output curves for this pathway, but this did not reach statistical significance in our studies. Intact LTP may reflect homeostatic compensation in the chronic condition with reduced synaptic numbers, but it precluded an assessment of $\mathrm{PrP}^{\mathrm{C}}$ 's in vivo role for CA1-LTP in this cohort of mice. Since some A $\beta$ plaque-bearing mouse strains do exhibit reduced hippocampal LTP (Nalbantoglu et al., 1997; Chapman et al., 1999; Moechars et al., 1999; Trinchese et al., 2004), the degree of chronic compensation may vary by age, strain, pathway, and transgene.

The phenotype of APPswe/PSen $1 \Delta \mathrm{E} 9$ mice most directly related to Alzheimer's disease is age-dependent memory impairment, and this was our primary outcome measure. Spatial learning and memory were examined in the Morris water maze (Morris, 1984) for the four groups of mice at 3 and 12 months of age. Visually cued performance was rapid in all four genotypes at 12 months of age (Fig. $4 a$, right). For hidden platform tests, mice were trained to one platform location, and then the platform position was reversed and training continued for the new location. At 12 months of age, the APP-PSen and the Prnp genotypes altered performance, and there was a significant interaction of the two genotypes [two-way repeated-measures (RM) ANOVA: APP-PSen $\times$ Prnp interaction, $p=0.015$; APP-PSen, $p<0.001$; Prnp, $p<0.001]$. Both wild-type and Prnp-/- mice learn the new location of the hidden platform over several trial blocks, and latencies to reach the platform approach those for visible platform locations (Fig. 4a). For APPswe/PSen $1 \Delta \mathrm{E} 9$ transgenic mice, learning is severely impaired with much longer latencies to reach a hidden platform. The learning of the APPswe/PSen $1 \Delta \mathrm{E} 9$ mice on the Prnp-/- background is indistinguishable from the control groups. By post hoc pairwise RM-ANOVA, the APPswe/ PSen $1 \Delta \mathrm{E} 9$ mice differ $(p<0.001)$ from each of the other three groups, and none of the other groups differ significantly from one another. For the APPswe/PSen $1 \Delta \mathrm{E} 9$ strain, enhanced learning was observed for both males and females lacking $\operatorname{PrP}^{\mathrm{C}}$ as compared to those with $\operatorname{PrP}^{\mathrm{C}}$ expression (Fig. 4b).

As an AD model, the PrP-dependent learning deficit of APPswe/PSen $1 \Delta \mathrm{E} 9$ mice is predicted to be an age-dependent phenomenon. Previously, we have shown that APPswe/PSen $1 \Delta$ E9 mice learn normally while young adults, but progressively exhibit learning deficits in a radial arm water maze from 6 to 12 months of age as $A \beta$ plaque develops (Park et al., 2006). Here, we examined Morris maze learning for each of the four genotypes at 3 months and 12 months (Fig. $4 c-g$ ). The APPswe/PSen $1 \Delta \mathrm{E} 9$ mice show a significant decline in learning over this period (Fig. 4e) (RM-ANOVA, $p<0.01$ ). None of the other strains exhibit an age-dependent decline in learning for this task. Thus, the Prnp-1- genotype interacts with APPswe/PSen $1 \Delta \mathrm{E} 9$ transgene to prevent the expression of an age-dependent learning deficit.

For the 12-month-old mice, the memory of learned platform locations was examined in a $60 \mathrm{~s}$ probe trial $2 \mathrm{~d}$ after the last learning trial (Fig. $4 h-j$ ). The wild-type and Prnp-l- mice prefer the location of the previously learned hidden platform, making significantly more platform crosses and spending more time in the platform location. In contrast, the APPswe/PSen $1 \Delta \mathrm{E} 9$ mice show no preference for the hidden platform location, and spend significantly less time in the target zone. The transgenic memory deficit is alleviated on the Prnp-/- background, demonstrating that $\operatorname{PrP}^{\mathrm{C}}$ is essential for impairment of memory by these $\mathrm{AD}$ transgenes in mice.

A second, but less specific, test of learning is passive avoidance. In this paradigm, wild-type mice exhibit an increased latency to enter a preferred dark chamber after receiving a footshock in that location (supplemental Fig. 2, available at www.jneurosci.org as supplemental material). The APPswe/ PSen $1 \Delta$ E9 mice enter the dark chamber significantly sooner, consistent with reduced learning or memory at $24 \mathrm{~h}$. In the absence of $\operatorname{PrP}^{\mathrm{C}}$, postshock latencies are statistically indistinguishable from wild-type mice regardless of the presence of the APPswe/PSen $1 \Delta$ E9 transgenic allele. Thus, on the Prnp-/background, the APPswe/PSen $1 \Delta \mathrm{E} 9$ passive avoidance deficit is not detectable.

\section{Discussion}

The major finding of this study is that memory deficits in $\mathrm{AD}$ transgenic mice require the presence of $\operatorname{PrP}^{\mathrm{C}}$. While previous studies had shown that synthetic $\mathrm{A} \beta$ oligomers bind to $\operatorname{PrP}^{\mathrm{C}}$ and depend on $\operatorname{PrP}^{\mathrm{C}}$ to suppress LTP in slices acutely (Laurén et al., 2009), the role of $\operatorname{PrP}^{\mathrm{C}}$ for in vivo toxicity of brain-derived $\mathrm{A} \beta$ had not been tested. The data here demonstrate a requirement of endogenous $\operatorname{PrP}^{\mathrm{C}}$ for the ability of familial $\mathrm{AD}$ transgenes to 

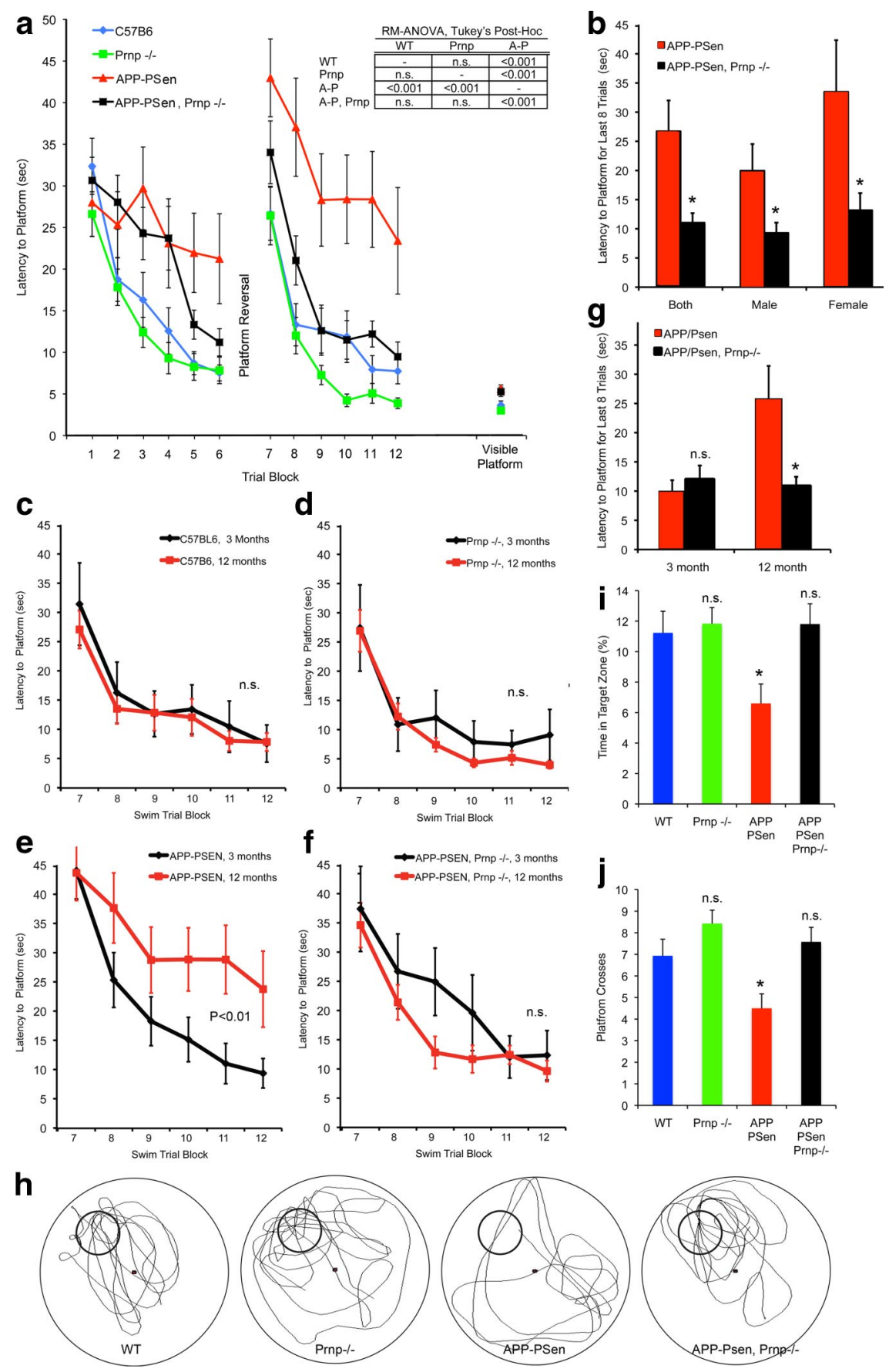

Figure 4. Deletion of PrP ${ }^{C}$ expression rescues spatial learning and memory in APPswe-PSen $1 \Delta E 9$ transgenic mice. $\boldsymbol{a}$, Spatial learning is plotted as the latency to find a hidden platform in the Morris water maze at 12 months of age. After the first set of swim trials, the platform location was reversed for the second set of trials. At a later time, after the probe trial, latency to reach a visible platform was scored. Data are mean \pm SEM for these groups: (57BL/6, $n=19$ (8 male, 11 female); Prnp $-/-n=15$ (7 male, 8 female); APP-PSen $n=11$ ( 6 male, 5 female); APP-PSen, Prnp $-/-n=20$ (11 male, 9 female). Performance differed by genotype across trial blocks 5-6 and 9-12 (two-way RM-ANOVA: APP-PSen by Prnp interaction, $p=0.015$; APP-PSen, $p<$ $0.001 ;$ Prnp, $p<0.001)$. For the indicated Tukey post hoc pairwise comparisons, the APP-PSen group differed from each of the other three groups $(p<0.001)$, but none of the other genotypes differed significantly from one another. $\boldsymbol{b}$, The performance of the APPswe/PSen $1 \Delta$ E 9 transgenic mice with and without PrP ${ }^{C}$ expression from trial blocks $11-12$ of $\boldsymbol{a}$ is separated by sex. The latencies are reduced in the Prnp $-/-$ groups compared to the Prnp $+/+$ groups, ${ }^{*} p<0.05$, two-tailed Student's $t$ test. c $\boldsymbol{f}$, Mice of each genotype were tested for spatial learning at 3 months, and the data are compared to the 12 month performance curves replotted from $\boldsymbol{a}$. By RM-ANOVA, only the APP-PSen group differed significantly $(p<0.05)$ between age groups. Data are mean \pm SEM for $n=11-20$ mice per group. $\boldsymbol{g}$, The performance of the APPswe/PSen $1 \Delta$ E9 transgenic mice with and without $\operatorname{PrP}{ }^{C}$ expression from trial blocks $11-12$ of $\boldsymbol{d}-\boldsymbol{f}$ is separated by age. The latencies are reduced in the Prnp - / - groups compared to the Prnp $+/+$ at 12 months but not 3 months, ${ }^{*} p<0.05$, two-tailed Student's $t$ test. $\boldsymbol{h}$, Two days after the second set of hidden platform learning trials from $\boldsymbol{a}, \mathrm{a} 60$ s probe trial was conducted. The swim track of one representative mouse from each of the four genotypes is illustrated. A small circle indicates the learned platform location. $\boldsymbol{i}, \boldsymbol{j}$, The time spent at the site of the previous platform induce several deficits. In addition to rescuing impairments in spatial memory, deletion of Prnp expression improved survival, and prevented loss of serotonin axons and synaptic markers. It is striking that APP and $\mathrm{A} \beta$ levels are not altered in APPswe/PSen $1 \Delta \mathrm{E} 9$ mice by the lack of $\operatorname{PrP}^{\mathrm{C}}$. In this regard, the effect of deleting $\operatorname{PrP}^{C}$ on mouse transgene phenotypes is similar to that of deleting Tau expression (Roberson et al., 2007). The dissociation of $\mathrm{A} \beta$ accumulation and dysfunction is consistent with $\operatorname{PrP}^{\mathrm{C}}$ functioning immediately downstream of $\mathrm{A} \beta$ oligomers in a pathological cascade. To the extent that certain deficits might be derived from the PSen $1 \Delta$ E9 transgene independently of APPswe (Zhang et al., 2009), they still require $\operatorname{PrP}^{\mathrm{C}}$ to be manifest.

Recently, Balducci et al. (2010) confirmed the direct binding of $A \beta$ oligomers to $\operatorname{PrP}^{\mathrm{C}}$ but reported that $\operatorname{PrP}^{\mathrm{C}}$ is not essential for $\mathrm{A} \beta$-induced memory deficits. This study used distinct methods from those used here. In place of AD transgenesis and spatial memory tests in the Morris water maze, the authors injected mice intracerebroventricularly with synthetic $\mathrm{A} \beta$ oligomer and examined object recognition memory. It may be significant that they synthesized a depsipeptide preparation and alkalinized it to induce conversion to the $A \beta$ itself. Some studies of transgenic APP mice have shown impairments of spatial learning but not object recognition (Chen et al., 2000), suggesting that the Balducci experiment may score $\mathrm{A} \beta$ actions distinct from, and less sensitive than, the genetic model. In their study, mice lacking $\operatorname{PrP}^{\mathrm{C}}$ show a typical preference for novelty, but after $\mathrm{A} \beta$ oligomer injection they show reversed behavior $[$ reversed discrimination $=$ negative $0.22 \pm 0.8$ in the study by Balducci et al. (2010), their Fig. 4C]. The reversal is not an absence of object memory, as in wild-type mice injected with $\mathrm{A} \beta$ oligomer. The $\mathrm{A} \beta$-oligomer-injected $\mathrm{PrP}^{\mathrm{C}}$ null mice actively avoid novel objects and prefer familiar objects. Since novelty seeking is reversed, an assessment of memory function is tenuous but, at face value, object memory is detectable in the $\mathrm{A} \beta$ oligomer-injected $\operatorname{PrP}^{\mathrm{C}}$-null mice. Thus, their method might be construed to support, rather than refute, the hypothesis

$\leftarrow$

location (i) and crosses of the previous platform location (j) are shown. Data are mean \pm SEM for $n=11-20$ mice per group. ${ }^{*} p<0.05$, one-way ANOVA with post hoc comparison to the WT group. 
that $\operatorname{PrP}^{C}$ is required for memory impairment by $A \beta$. Clearly, $A \beta$ has an unexplained action in this experiment that alters preference for novelty versus familiarity, possibly via arousal or anxiety (Berlyne, 1966; Berlyne et al., 1966; Mumby, 2001). Regardless of these uncertainties regarding the acute synthetic $\mathrm{A} \beta$ injection model, our studies demonstrate that $\mathrm{PrP}^{\mathrm{C}}$ is essential for APP/ PSen transgenic memory and survival deficits.

The molecular events that link $\mathrm{A} \beta$ oligomer binding to $\operatorname{PrP}^{\mathrm{C}}$ with subsequent loss of synaptic markers, 5-HT axon degeneration, survival, and memory function are not yet defined. Several other neurodegenerative conditions are not dependent on $\mathrm{PrP}^{\mathrm{C}}$ (Steele et al., 2009), so there is specificity for APP/A $\beta$-dependent phenotypes. Similar to $\mathrm{A} \beta$ oligomers, misfolded infectious $\mathrm{PrP}^{\mathrm{Sc}}$ requires $\operatorname{PrP}^{\mathrm{C}}$ to induce neurotoxicity. The requirement of $\operatorname{PrP}^{\mathrm{C}}$ for degeneration as opposed to infection has been demonstrated by the infection of grafted wild-type brain tissue in Prnp-/hosts (Brandner et al., 1996), and the requirement for neuronal $\mathrm{PrP}^{\mathrm{C}}$ (Mallucci et al., 2003) and membrane-anchored $\mathrm{PrP}^{\mathrm{C}}$ (Chesebro et al., 2005) for neurotoxicity. Since $\operatorname{PrP}^{\mathrm{C}}$ is a lipidanchored cell surface protein, it is presumably coupled to transmembrane proteins and intracellular signal transduction, but which associated proteins are relevant for these degenerative phenotypes is not known. The proteome of $\mathrm{PrP}^{\mathrm{C}}$-associated proteins (Schmitt-Ulms et al., 2004) and the neurodegeneration of mice expressing truncated $\operatorname{PrP}^{\mathrm{C}}$ (Baumann et al., 2007; Li et al., 2007) may facilitate future mechanistic studies.

In the constitutive Prnp mutant, loss of $\operatorname{PrP}^{\mathrm{C}}$ expression throughout life rescues memory deficits in the transgenic mice. It is not clear which phenotypes might be reversible if $\mathrm{PrP}^{\mathrm{C}}$ expression or $\mathrm{A} \beta$-oligomer binding were blocked at some point after the onset of AD-related deficits. However, further molecular and pharmacological analysis should define the potential utility of $\operatorname{PrP}^{\mathrm{C}}$ blockade in alleviating $\mathrm{AD}$ onset, progression, and symptoms.

\section{References}

Austin MC, Whitehead RE, Edgar CL, Janosky JE, Lewis DA (2002) Localized decrease in serotonin transporter-immunoreactive axons in the prefrontal cortex of depressed subjects committing suicide. Neuroscience 114:807-815.

Balducci C, Beeg M, Stravalaci M, Bastone A, Sclip A, Biasini E, Tapella L, Colombo L, Manzoni C, Borsello T, Chiesa R, Gobbi M, Salmona M, Forloni G (2010) Synthetic amyloid-beta oligomers impair long-term memory independently of cellular prion protein. Proc Natl Acad Sci U S A 107:2295-2300.

Baumann F, Tolnay M, Brabeck C, Pahnke J, Kloz U, Niemann HH, Heikenwalder M, Rülicke T, Bürkle A, Aguzzi A (2007) Lethal recessive myelin toxicity of prion protein lacking its central domain. EMBO J 26:538-547.

Berlyne DE (1966) Curiosity and exploration. Science 153:25-33.

Berlyne DE, Koenig ID, Hirota T (1966) Novelty, arousal, and the reinforcement of diversive exploration in the rat. J Comp Physiol Psychol 62:222-226.

Biscaro B, Lindvall O, Hock C, Ekdahl CT, Nitsch RM (2009) A $\beta$ immunotherapy protects morphology and survival of adult-born neurons in doubly transgenic APP/PS1 mice. J Neurosci 29:14108-14119.

Brandner S, Isenmann S, Raeber A, Fischer M, Sailer A, Kobayashi Y, Marino S, Weissmann C, Aguzzi A (1996) Normal host prion protein necessary for scrapie-induced neurotoxicity. Nature 379:339-343.

Buttini M, Orth M, Bellosta S, Akeefe H, Pitas RE, Wyss-Coray T, Mucke L, Mahley RW (1999) Expression of human apolipoprotein E3 or E4 in the brains of Apoe-/- mice: isoform-specific effects on neurodegeneration. J Neurosci 19:4867-4880.

Buttini M, Masliah E, Barbour R, Grajeda H, Motter R, Johnson-Wood K, Khan K, Seubert P, Freedman S, Schenk D, Games D (2005) $\beta$-Amyloid immunotherapy prevents synaptic degeneration in a mouse model of Alzheimer's disease. J Neurosci 25:9096-9101.

Chapman PF, White GL, Jones MW, Cooper-Blacketer D, Marshall VJ,
Irizarry M, Younkin L, Good MA, Bliss TV, Hyman BT, Younkin SG, Hsiao KK (1999) Impaired synaptic plasticity and learning in aged amyloid precursor protein transgenic mice. Nat Neurosci 2:271-276.

Chen G, Chen KS, Knox J, Inglis J, Bernard A, Martin SJ, Justice A, McConlogue L, Games D, Freedman SB, Morris RG (2000) A learning deficit related to age and beta-amyloid plaques in a mouse model of Alzheimer's disease. Nature 408:975-979.

Chesebro B, Trifilo M, Race R, Meade-White K, Teng C, LaCasse R, Raymond L, Favara C, Baron G, Priola S, Caughey B, Masliah E, Oldstone M (2005) Anchorless prion protein results in infectious amyloid disease without clinical scrapie. Science 308:1435-1439.

Chin J, Palop JJ, Yu GQ, Kojima N, Masliah E, Mucke L (2004) Fyn kinase modulates synaptotoxicity, but not aberrant sprouting, in human amyloid precursor protein transgenic mice. J Neurosci 24:4692-4697.

Cleary JP, Walsh DM, Hofmeister JJ, Shankar GM, Kuskowski MA, Selkoe DJ, Ashe KH (2005) Natural oligomers of the amyloid-beta protein specifically disrupt cognitive function. Nat Neurosci 8:79-84.

Davies CA, Mann DM, Sumpter PQ, Yates PO (1987) A quantitative morphometric analysis of the neuronal and synaptic content of the frontal and temporal cortex in patients with Alzheimer's disease. J Neurol Sci 78: 151-164.

Duffy P, Schmandke A, Schmandke A, Sigworth J, Narumiya S, Cafferty WB, Strittmatter SM (2009) Rho-associated kinase II (ROCKII) limits axonal growth after trauma within the adult mouse spinal cord. J Neurosci 29:15266-15276.

Fitzjohn SM, Morton RA, Kuenzi F, Rosahl TW, Shearman M, Lewis H, Smith D, Reynolds DS, Davies CH, Collingridge GL, Seabrook GR (2001) Agerelated impairment of synaptic transmission but normal long-term potentiation in transgenic mice that overexpress the human APP695SWE mutant form of amyloid precursor protein. J Neurosci 21:4691-4698.

GrandPré T, Li S, Strittmatter SM (2002) Nogo-66 receptor antagonist peptide promotes axonal regeneration. Nature 417:547-551.

Grider MH, Chen Q, Shine HD (2006) Semi-automated quantification of axonal densities in labeled CNS tissue. J Neurosci Methods 155:172-179.

Gureviciene I, Ikonen S, Gurevicius K, Sarkaki A, van Groen T, Pussinen R, Ylinen A, Tanila H (2004) Normal induction but accelerated decay of LTP in APP + PS1 transgenic mice. Neurobiol Dis 15:188-195.

Halford RW, Russell DW (2009) Reduction of cholesterol synthesis in the mouse brain does not affect amyloid formation in Alzheimer's disease, but does extend lifespan. Proc Natl Acad Sci U S A 106:3502-3506.

Hsia AY, Masliah E, McConlogue L, Yu GQ, Tatsuno G, Hu K, Kholodenko D, Malenka RC, Nicoll RA, Mucke L (1999) Plaque-independent disruption of neural circuits in Alzheimer's disease mouse models. Proc Natl Acad Sci U S A 96:3228-3233.

Jankowsky JL, Fadale DJ, Anderson J, Xu GM, Gonzales V, Jenkins NA, Copeland NG, Lee MK, Younkin LH, Wagner SL, Younkin SG, Borchelt DR (2004) Mutant presenilins specifically elevate the levels of the 42 residue betaamyloid peptide in vivo: evidence for augmentation of a 42 -specific gamma secretase. Hum Mol Genet 13:159-170.

Kim JE, Liu BP, Park JH, Strittmatter SM (2004) Nogo-66 receptor prevents raphespinal and rubrospinal axon regeneration and limits functional recovery from spinal cord injury. Neuron 44:439-451.

King SL, Marks MJ, Grady SR, Caldarone BJ, Koren AO, Mukhin AG, Collins AC, Picciotto MR (2003) Conditional expression in corticothalamic efferents reveals a developmental role for nicotinic acetylcholine receptors in modulation of passive avoidance behavior. J Neurosci 23:3837-3843.

Lambert MP, Barlow AK, Chromy BA, Edwards C, Freed R, Liosatos M, Morgan TE, Rozovsky I, Trommer B, Viola KL, Wals P, Zhang C, Finch CE, Krafft GA, Klein WL (1998) Diffusible, nonfibrillar ligands derived from Abeta1-42 are potent central nervous system neurotoxins. Proc Natl Acad Sci U S A 95:6448-6453.

Larson J, Lynch G, Games D, Seubert P (1999) Alterations in synaptic transmission and long-term potentiation in hippocampal slices from young and aged PDAPP mice. Brain Res 840:23-35.

Laurén J, Gimbel DA, Nygaard HB, Gilbert JW, Strittmatter SM (2009) Cellular prion protein mediates impairment of synaptic plasticity by amyloid-beta oligomers. Nature 457:1128-1132.

Lesné S, Koh MT, Kotilinek L, Kayed R, Glabe CG, Yang A, Gallagher M, Ashe $\mathrm{KH}$ (2006) A specific amyloid-beta protein assembly in the brain impairs memory. Nature 440:352-357.

Li A, Christensen HM, Stewart LR, Roth KA, Chiesa R, Harris DA (2007) 
Neonatal lethality in transgenic mice expressing prion protein with a deletion of residues 105-125. EMBO J 26:548-558.

Li S, Liu BP, Budel S, Li M, Ji B, Walus L, Li W, Jirik A, Rabacchi S, Choi E, Worley D, Sah DW, Pepinsky B, Lee D, Relton J, Strittmatter SM (2004) Blockade of nogo-66, myelin-associated glycoprotein, and oligodendrocyte myelin glycoprotein by soluble nogo-66 receptor promotes axonal sprouting and recovery after spinal injury. J Neurosci 24:10511-10520.

Li S, Kim JE, Budel S, Hampton TG, Strittmatter SM (2005) Transgenic inhibition of Nogo-66 receptor function allows axonal sprouting and improved locomotion after spinal injury. Mol Cell Neurosci 29:26-39.

Linhoff MW, Laurén J, Cassidy RM, Dobie FA, Takahashi H, Nygaard HB, Airaksinen MS, Strittmatter SM, Craig AM (2009) An unbiased expression screen for synaptogenic proteins identifies the LRRTM protein family as synaptic organizers. Neuron 61:734-749.

Liu Y, Yoo MJ, Savonenko A, Stirling W, Price DL, Borchelt DR, Mamounas L, Lyons WE, Blue ME, Lee MK (2008) Amyloid pathology is associated with progressive monoaminergic neurodegeneration in a transgenic mouse model of Alzheimer's disease. J Neurosci 28:13805-13814.

Mallucci G, Dickinson A, Linehan J, Klöhn PC, Brandner S, Collinge J (2003) Depleting neuronal PrP in prion infection prevents disease and reverses spongiosis. Science 302:871-874.

Mamounas LA, Altar CA, Blue ME, Kaplan DR, Tessarollo L, Lyons WE (2000) BDNF promotes the regenerative sprouting, but not survival, of injured serotonergic axons in the adult rat brain. J Neurosci 20:771-782.

Manson JC, Clarke AR, Hooper ML, Aitchison L, McConnell I, Hope J (1994) 129/Ola mice carrying a null mutation in PrP that abolishes mRNA production are developmentally normal. Mol Neurobiol 8:121-127.

Masliah E, Ellisman M, Carragher B, Mallory M, Young S, Hansen L, DeTeresa R, Terry RD (1992) Three-dimensional analysis of the relationship between synaptic pathology and neuropil threads in Alzheimer disease. J Neuropathol Exp Neurol 51:404-414.

Minkeviciene R, Rheims S, Dobszay MB, Zilberter M, Hartikainen J, Fülöp L, Penke B, Zilberter Y, Harkany T, Pitkänen A, Tanila H (2009) Amyloid $\beta$-induced neuronal hyperexcitability triggers progressive epilepsy. J Neurosci 29:3453-3462.

Moechars D, Dewachter I, Lorent K, Reversé D, Baekelandt V, Naidu A, Tesseur I, Spittaels K, Haute CV, Checler F, Godaux E, Cordell B, Van Leuven F (1999) Early phenotypic changes in transgenic mice that overexpress different mutants of amyloid precursor protein in brain. J Biol Chem 274:6483-6492.

Morris R (1984) Developments of a water-maze procedure for studying spatial learning in the rat. J Neurosci Methods 11:47-60.

Mucke L, Yu GQ, McConlogue L, Rockenstein EM, Abraham CR, Masliah E (2000a) Astroglial expression of human alpha(1)-antichymotrypsin enhances Alzheimer-like pathology in amyloid protein precursor transgenic mice. Am J Pathol 157:2003-2010.

Mucke L, Masliah E, Yu GQ, Mallory M, Rockenstein EM, Tatsuno G, Hu K, Kholodenko D, Johnson-Wood K, McConlogue L (2000b) High-level neuronal expression of $\mathrm{A} \beta_{1-42}$ in wild-type human amyloid protein precursor transgenic mice: synaptotoxicity without plaque formation. J Neurosci 20:4050-4058.

Mumby DG (2001) Perspectives on object-recognition memory following hippocampal damage: lessons from studies in rats. Behav Brain Res 127:159-181.

Nalbantoglu J, Tirado-Santiago G, Lahsaïni A, Poirier J, Goncalves O, Verge G, Momoli F, Welner SA, Massicotte G, Julien JP, Shapiro ML (1997) Impaired learning and LTP in mice expressing the carboxy terminus of the Alzheimer amyloid precursor protein. Nature 387:500-505.

Palop JJ, Chin J, Roberson ED, Wang J, Thwin MT, Bien-Ly N, Yoo J, Ho KO, Yu GQ, Kreitzer A, Finkbeiner S, Noebels JL, Mucke L (2007) Aberrant excitatory neuronal activity and compensatory remodeling of inhibitory hippocampal circuits in mouse models of Alzheimer's disease. Neuron 55:697-711.

Park JH, Widi GA, Gimbel DA, Harel NY, Lee DH, Strittmatter SM (2006) Subcutaneous Nogo receptor removes brain amyloid- $\beta$ and improves spatial memory in Alzheimer's transgenic mice. J Neurosci 26:1327913286.

Parkin ET, Watt NT, Hussain I, Eckman EA, Eckman CB, Manson JC, Baybutt HN, Turner AJ, Hooper NM (2007) Cellular prion protein regulates betasecretase cleavage of the Alzheimer's amyloid precursor protein. Proc Natl Acad Sci U S A 104:11062-11067.

Roberson ED, Scearce-Levie K, Palop JJ, Yan F, Cheng IH, Wu T, Gerstein H, Yu GQ, Mucke L (2007) Reducing endogenous tau ameliorates amyloid beta-induced deficits in an Alzheimer's disease mouse model. Science 316:750-754.

Roder S, Danober L, Pozza MF, Lingenhoehl K, Wiederhold KH, Olpe HR (2003) Electrophysiological studies on the hippocampus and prefrontal cortex assessing the effects of amyloidosis in amyloid precursor protein 23 transgenic mice. Neuroscience 120:705-720.

Scheff SW, DeKosky ST, Price DA (1990) Quantitative assessment of cortical synaptic density in Alzheimer's disease. Neurobiol Aging 11:29-37.

Schmitt-Ulms G, Hansen K, Liu J, Cowdrey C, Yang J, DeArmond SJ, Cohen FE, Prusiner SB, Baldwin MA (2004) Time-controlled transcardiac perfusion cross-linking for the study of protein interactions in complex tissues. Nat Biotechnol 22:724-731.

Schwarze-Eicker K, Keyvani K, Görtz N, Westaway D, Sachser N, Paulus W (2005) Prion protein $(\mathrm{PrPc})$ promotes beta-amyloid plaque formation. Neurobiol Aging 26:1177-1182.

Shankar GM, Li S, Mehta TH, Garcia-Munoz A, Shepardson NE, Smith I, Brett FM, Farrell MA, Rowan MJ, Lemere CA, Regan CM, Walsh DM, Sabatini BL, Selkoe DJ (2008) Amyloid-beta protein dimers isolated directly from Alzheimer's brains impair synaptic plasticity and memory. Nat Med 14:837-842.

Steele AD, Zhou Z, Jackson WS, Zhu C, Auluck P, Moskowitz MA, Chesselet MF, Lindquist S (2009) Context dependent neuroprotective properties of prion protein $(\operatorname{PrP})$. Prion 3:240-249.

Trinchese F, Liu S, Battaglia F, Walter S, Mathews PM, Arancio O (2004) Progressive age-related development of Alzheimer-like pathology in APP/ PS1 mice. Ann Neurol 55:801-814.

Volianskis A, Kostner R, Molgaard M, Hass S, Jensen MS (2008) Episodic memory deficits are not related to altered glutamatergic synaptic transmission and plasticity in the CAl hippocampus of the APPswe/ PS1DeltaE9-deleted transgenic mice model of beta-amyloidosis. Neurobiol Aging. Advance online publication. Retrieved April 12, 2010. doi: 10.1016/ j.neurobiolaging.2008.08.005.

Vorhees CV, Williams MT (2006) Morris water maze: procedures for assessing spatial and related forms of learning and memory. Nat Protoc 1:848-858.

Walsh DM, Klyubin I, Fadeeva JV, Cullen WK, Anwyl R, Wolfe MS, Rowan MJ, Selkoe DJ (2002) Naturally secreted oligomers of amyloid beta protein potently inhibit hippocampal long-term potentiation in vivo. Nature 416:535-539.

Wang X, Baughman KW, Basso DM, Strittmatter SM (2006) Delayed Nogo receptor therapy improves recovery from spinal cord contusion. Ann Neurol 60:540-549.

Wang X, Budel S, Baughman K, Gould G, Song KH, Strittmatter SM (2009) Ibuprofen enhances recovery from spinal cord injury by limiting tissue loss and stimulating axonal growth. J Neurotrauma 26:81-95.

Zhang C, Wu B, Beglopoulos V, Wines-Samuelson M, Zhang D, Dragatsis I, Südhof TC, Shen J (2009) Presenilins are essential for regulating neurotransmitter release. Nature 460:632-636. 